\section{Molecular Syndromology}

Mol Syndromol 2010;1:75-81

DOI: $\underline{10.1159 / 000314025}$
Accepted: April 14, 2010

Published online: June 9, 2010

\title{
Interstitial Deletions at 6q14.1-q15 Associated with Obesity, Developmental Delay and a Distinct Clinical Phenotype
}

\author{
C. Wentzel ${ }^{a} \quad$ S.A. Lynch ${ }^{\text {b }} \quad$ E.-L. Stattin ${ }^{\text {C }}$ F.H. Sharkey ${ }^{d} \quad$ G. Annerén ${ }^{a}$ \\ A.-C. Thuresson ${ }^{a}$

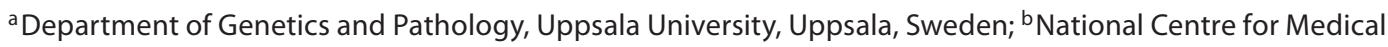 \\ Genetics, OLCHC, Dublin, Ireland; ' ${ }^{2}$ Department of Medical Biosciences, Medical and Clinical Genetics, Umeå \\ University, Umeå, Sweden; ${ }^{\mathrm{d}}$ Microarray Unit, Cytogenetics Laboratory, Western General Hospital, Edinburgh, UK
}

\section{Key Words}

$6 \mathrm{q}$ Deletion · Learning disability $\cdot$ Mental retardation • Obesity

\begin{abstract}
Background: Interstitial deletions of the long arm of chromosome 6 have been described in several patients with obesity and a Prader-Willi-like phenotype. Haploinsufficiency of the SIM1 gene located at 6 q16.3 is suggested as being responsible for the regulation of body weight. Here we report on 2 patients with interstitial deletions at 6q14.1-q15 presenting with obesity and symptoms strikingly similar to those reported for deletions involving the SIM1 gene despite not having a deletion of this gene. Methods: Array comparative genomic hybridisation was used to diagnose 2 children with obesity and developmental delay, revealing 2 interstitial deletions at $6 q 14.1-q 15$ of 8.73 and $4.50 \mathrm{Mb}$, respectively, and a region of overlap of $4.2-\mathrm{Mb}$. Results: The similar phenotype in the 2 patients was most likely due to a 4.2-Mb common microdeletion at 6q14.1-q15. Another patient has previously been described with an overlapping deletion. The 3 patients share several features, such as developmental delay, obesity, hernia, rounded face with full cheeks, epicanthal folds, short palpebral fissures, bulbous nose, large ears, and syndactyly between toes II and III. Conclusions: Together
\end{abstract}

with a previously reported patient, our study suggests that the detected deletions may represent a novel clinically recognisable microdeletion syndrome caused by haploinsufficiency of dosage-sensitive genes in the 6q14.1-q15 region.

Copyright $\odot 2010$ S. Karger AG, Basel

\section{Introduction}

For several years, rare copy number variants (CNV) have been known to be the cause of many developmental diseases [Lee and Lupski, 2006], and many new syndromes have been discovered since genomic arrays were implemented as a diagnostic tool in clinical settings to search for the cause of idiopathic mental retardation in children. Several rare CNVs have been detected in patients suffering from mental retardation and early-onset obesity [Bonaglia et al., 2008; Bochukova et al., 2010; Walters et al., 2010]. A number of single nucleotide polymorphisms (SNPs) has, in recent genome-wide association studies, also been associated with obesity [Walley et al., 2009].

In the reported cases with deletions at chromosome $6 \mathrm{q}$, there are large phenotypic variations due to differences in the size and location of the deletion [Turleau et

\section{KARGER}

Fax +41613061234 E-Mail karger@karger.ch www.karger.com

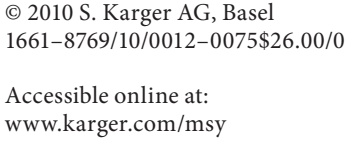

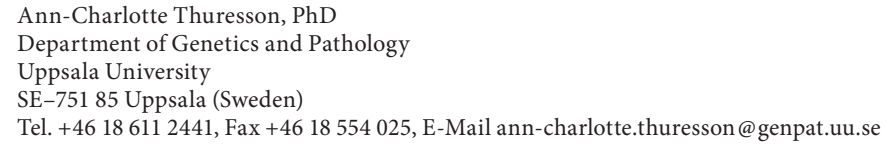




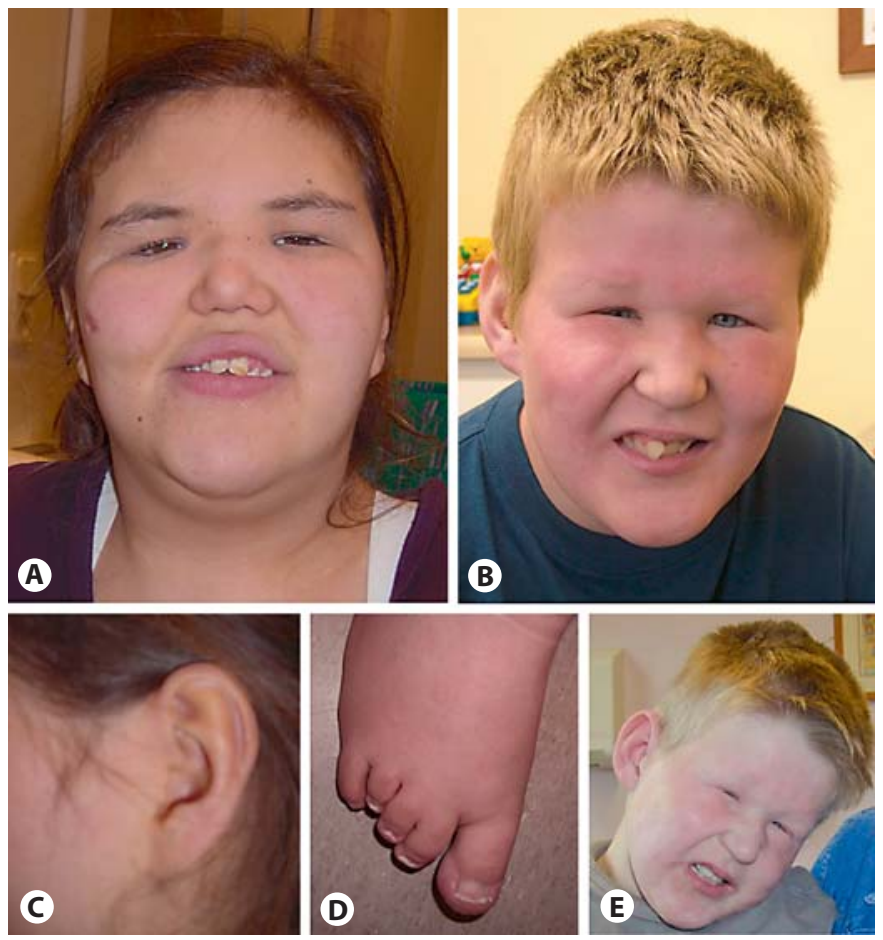

Fig. 1. A Patient 1 at the age of 17 years. B Patient 2 at the age of 12.5 years. C Ear. D Foot with brachymetatarsalia of the 4 th toe of patient 1. E Patient 2.

al., 1988; Villa et al., 1995; Stein et al., 1996; Hopkin et al., 1997; Gilhuis et al., 2000; Faivre et al., 2002; Grati et al., 2005; Le Caignec et al., 2005; Varela et al., 2006; Klein et al., 2007; Bonaglia et al., 2008]. In a review of 60 patients by Hopkin et al. [1997], 3 distinct phenotypes were described on the basis of the location of the $6 \mathrm{q}$ deletion. In group A, del(6)(q11-q16), there was a high incidence of hernias, up-slanting palpebral fissures and thin lips. This deletion was also associated with microcephaly, micrognathia and cardiac malformations.

So far, reports on 8 patients presenting with a 6q deletion and a Prader-Willi-like phenotype, including obesity, have been published. Seven of the 8 patients featured a deletion of the 6q16.2-q16.3 region. Haploinsufficiency of the SIM1 gene (MIM 603128), located in this region, has been suggested as a possible cause of the obesity [Villa et al., 1995; Faivre et al., 2002; Bonaglia et al., 2008].

In this report, we present 2 patients with developmental delay with an interstitial deletion of 6q14.1-6q15. Although these patients did not have a deletion at the $6 \mathrm{q} 16.3$ region encompassing the SIM1 gene, they have most of the symptoms in common with these patients, suggesting that other genes might cause the obesity in these patients.
Another patient has previously been reported with a deletion overlapping this region and a phenotype similar to the patients in this study [Turleau et al., 1988]. The shared clinical features of the 3 patients include developmental delay, obesity, hernia, rounded face with full cheeks, epicanthal folds, short palpebral fissures, bulbous nose, large ears, and syndactyly between toes II and III.

\section{Materials and Methods}

\section{Patients}

The clinical investigations and genetic analyses were performed according to the guidelines in the Declaration of Helsinki and were approved by the ethics committee at Uppsala University. Informed consent was obtained from the families. Genomic DNA was extracted from peripheral blood leukocytes from patients using standard procedures.

\section{Array Comparative Genomic Hybridisation}

Microarray-based comparative genomic hybridisation (array CGH) was performed using the CytoChip (BlueGnome Ltd., Cambridge, UK), as previously described [Wentzel et al., 2008]. To confirm the results and map breakpoints, an Affymetrix ${ }^{\circledR} \mathrm{Ge}$ nome-Wide SNP Array 6.0 (Affymetrix Inc., Santa Clara, Calif., USA) was performed in accordance with the manufacturer's instructions. Data analysis of Affymetrix data was carried out with Genotyping Console 3.0.2.

\section{$M L P A$}

Confirmation of array CGH data and parental analysis of patient 1 was carried out by using 3 specifically designed synthetic MLPA probes designed to cover the region of interest [Stern et al. 2004], as previously described [Thuresson et al., 2007]. Data analysis was performed with GeneMarker software 1.85 (Softgenetics, State College, PA, USA).

\section{FISH}

Confirmation of array CGH data and maternal analysis of patient 2 was performed by FISH analysis using bacterial artificial chromosome probes within the deleted region and using standard techniques [Chong et al. 1997].

\section{Case Reports}

\section{Patient 1}

This 17-year-old girl (fig. 1A, C, D) is the first child born to non-consanguineous, healthy parents. The mother's brother had mental retardation, probably due to a viral infection in the neonatal period. The father's 2 cousins, born by the same parents, were mentally retarded; the causes for the retardation remain unknown.

The pregnancy was described as uneventful, apart from a few days of severe maternal vertigo at the end of 
the pregnancy period. The proband was born by vaginal delivery after the $42 \mathrm{nd}$ week of gestation. Her birth weight was $2,800 \mathrm{~g}(-2 \mathrm{SD})$, length $49 \mathrm{~cm}(-0.5 \mathrm{SD})$ and head circumference $37 \mathrm{~cm}(+2 \mathrm{SD})$. She had muscle hypotonia with failure to thrive during the neonatal period. During childhood she was short in stature but grew according to her growth chart.

Psychomotor development was delayed. At 17 months, she had reached the developmental milestones of a $7-10$-month-old child. She started to crawl at the age of 2-3 years, to sit at 4 years and to walk, with support, at 4.5 years of age. At 7 years of age, she was still not able to walk without support. She spoke her first words when she was 3 years old. Clinical examination at the age of one year showed the following dysmorphic features: a large head with a prominent occipital and frontal region and a narrow bi-temporal diameter, thin hair, full round cheeks, short and down-slanting palpebral fissures, epicanthal folds, entropion of one lower eyelid, a broad nasal bridge, a bulbous nose tip, a high palate, a thin upper lip, and a tented mouth. The hands and feet were small and obese with fragile nails. She had syndactyly between the second and the third toe bilaterally. At birth, she had an umbilical hernia and a fistula in the sacral region, later both healed spontaneously. From about the age of 7 years, she started to become obese. At 5 years of age, bilateral hyperopia was found and at 15 years progressive cataract in the right eye was diagnosed. She had a hearing deficiency of $30 \mathrm{db}$ bilaterally. Menarche occurred at 15 years of age.

There was a heart murmur, but cardiac ultrasonographic findings were normal. Her renal function was deficient as a result of chronic pyelonephritis and a malformation of the right kidney; she was treated with daily antibiotics. Routine biochemical and metabolic screening was normal. Cerebral CT showed wide ventricles and a partial corpus callosum agenesis. She attended a special school for children with developmental delay.

At re-evaluation at the age of 4 , her weight was $18.2 \mathrm{~kg}$ and height $98 \mathrm{~cm}$ (BMI 19); at 4 years and 9 months, weight was $20.1 \mathrm{~kg}$ and height $102 \mathrm{~cm}$ (BMI 19.3); at 5 years and 11 months, weight was $25.2 \mathrm{~kg}$ and height $109 \mathrm{~cm}$ (BMI 21.2); at 7 years, weight was $33.7 \mathrm{~kg}$ and height $116.5 \mathrm{~cm}$ (BMI 25). Her occipito-frontal head circumference (OFHC) at birth was $\pm 2 \mathrm{SD}$; at 9 months $\pm 3 \mathrm{SD}$, at 4 years $\pm 2 \mathrm{SD}$ and at 8 years $\pm 3 \mathrm{SD}$. At the last clinical examination at 17 years of age, the patient (fig. $1 \mathrm{~A}, \mathrm{C}, \mathrm{D}$ ) was able to walk without support for a short distance; she spoke in short sentences of 2-3 words but understood much more. Her height was $151 \mathrm{~cm}$, which was short compared with her target height of $165 \mathrm{~cm}$. Her weight was $70 \mathrm{~kg}$ (BMI
30.7), and she still ate a lot, but she was not 'bottomless' and said no to food when she was full. She had attention deficit and aggressive tantrums. OFHC was \pm 3 SD.

\section{Patient 2}

This male patient (fig. 1B) was born by ventouse delivery at 42 weeks after an unremarkable pregnancy. The birth weight was $3,630 \mathrm{~g}( \pm 0 \mathrm{SD})$. There were early feeding difficulties. He was noted to have camptodactyly of the 3 middle fingers of his right hand. He had a right inguinal hernia corrected by operative surgery at 9 months. His eyes were deep-set and appeared shut, resulting in early referral to ophthalmology. He was noted to have a very small angle esophoria with fine horizontal nystagmus. He had hyperopic astigmatism and mild ptosis. The rest of his ocular examination was normal. He had surgery for a twisted epididymis when he was 4 years old. He had grommets and adenoids removed in early childhood. He was noted to have early scoliosis which improved later in childhood. He had mild to moderate developmental delay and a severe dyspraxia. He entered puberty at the appropriate age and there are no signs of hypogonadism. $\mathrm{He}$ can walk and run but is described as awkward. Fine motor skills, such as holding a pencil, are poor. He cannot ride a bike but can manage a go-cart. He can dress himself but tends to put clothes on back to front and inside out. He cannot read or write and can only produce 3 -worded sentences. He is hyperactive and exhibits foodseeking behaviour. The kitchen is locked at night. He started to become obese when he was 5 years old.

At re-evaluation at 3.3 years of age, his weight was 23 $\mathrm{kg}(+3 \mathrm{SD})$, height $106.5 \mathrm{~cm}(+2 \mathrm{SD}$; BMI 20.3) and OFHC $52.5 \mathrm{~cm}(+2 \mathrm{SD})$; at 13 years and 10 months, his weight was $79.6 \mathrm{~kg}$, height $173 \mathrm{~cm}$ (BMI 26.6) and OFHC $58 \mathrm{~cm}$. He wore size 43 shoes at the age of 14 . He had fixed flexion deformities of both elbows, restriction in pronation in the right forearm and restriction in supination in the left forearm. He had a mild pectus excavatum, inverted nipples and a café au lait patch on the right side of his chest. Due to pectus excavatum an X-ray of the chest was performed, which showed suspected cardiomegaly. The ultrasound of the heart was normal, but the ECG revealed mild right ventricular conduction delay.

\section{Results}

\section{Patient 1}

Chromosomal karyotyping was normal. Owing to the obesity and the Prader-Willi-like phenotype, a Prader- 


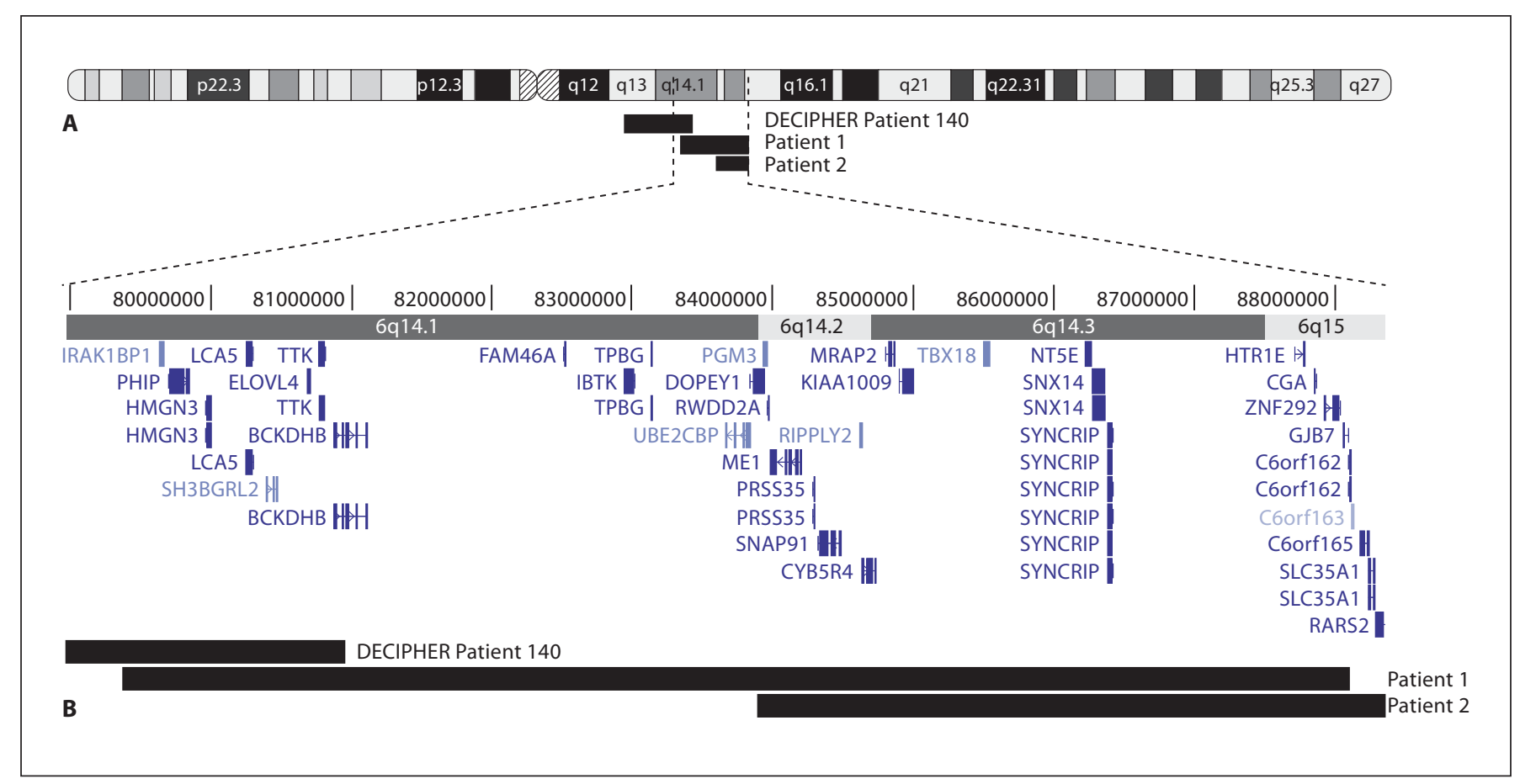

Fig. 2. A Idiogram of chromosome 6 displaying the deletions at $6 \mathrm{q} 14.1-\mathrm{q} 15$ in patients 1 , 2, and patient 140 reported in DECIPHER. B Enlargement of deleted region of present 2 cases and patient 140 in DECIPHER and genes involved in the region of interest.

Willi syndrome methylation test was carried out and proved normal. At 16 years of age, array CGH-analysis revealed a de novo deletion at $6 \mathrm{q} 14.1-\mathrm{q} 15$. To further refine the breakpoints, an Affymetrix SNP Array 6.0 analysis was performed, which determined the centromeric breakpoint to be located at 79,381,592 (hg18)(SNP_A2113875) at 6q14.1, and the telomeric breakpoint at $88,101,121$ (hg18)(SNP_A-1882803) at 6q15 (fig. 2A). The size of the deletion was estimated to be $8.73 \mathrm{Mb}$.

\section{Patient 2}

Chromosomal karyotyping and telomeres by MLPA were normal. Array CGH analysis revealed $2 \mathrm{CNVs}$, one duplication at $1 \mathrm{p} 31.1$ and one deletion at $6 \mathrm{q} 14.1-\mathrm{q} 15$. To further refine the breakpoints, an Affymetrix SNP Array 6.0 analysis was performed, which determined the $1 \mathrm{p} 31.1$ duplication to encompass the region between 72,618,778$75,171,956$ (hg18; SNP_A-8687482 to CN_500319) and the 6q14.1-q15 deletion to be located between 83,890,115$88,391,069$ (CN_1200346 to CN_1189450) (fig. 2A). The estimated sizes of the CNVs were $2.55 \mathrm{Mb}$ and $4.50 \mathrm{Mb}$, respectively. The CNVs could not be detected in the mother. DNA from the father was not available.

\section{Discussion}

Prader-Willi syndrome is the most well-known obesity-associated syndrome and is characterised by hypotonia, craniofacial abnormalities, hypogonadism, a short stature, small hands and feet, hyperphagia, and developmental delay. The incidence is $1 / 15-25,000$ per live births. Early-onset obesity in combination with a developmental disorder was recently also reported in patients with a deletion at 16p11.2 [Bochukova et al., 2010; Walters et al., 2010] and has also been observed in a majority of patients with deletions within the 6q15-q23.1 region [Turleau et al., 1988; Villa et al., 1995; Stein et al., 1996; Gilhuis et al., 2000; Faivre et al., 2002; Varela et al., 2006; Bonaglia et al., 2008].

Here we report on 2 patients with interstitial deletions at 6q14.1-q15 which have early-onset obesity and a developmental delay. Patient 2 also has an additional duplication at 1p31.1. In the literature, there has been a report on a patient with an overlapping deletion at 6q14-q16.2 [Turleau et al., 1988]. Comparing the phenotype of these 3 patients, the common features present are striking (fig. 1A, $\mathrm{B}$; table 1). Apart from the developmental delay present in 
Table 1. Summary of clinical features of present and previously reported cases with a deletion at $6 \mathrm{q} 14-\mathrm{q} 23.1$

\begin{tabular}{|c|c|c|c|c|c|}
\hline & $\begin{array}{l}\text { Present } \\
\text { patient } 1\end{array}$ & $\begin{array}{l}\text { Present } \\
\text { patient } 2\end{array}$ & $\begin{array}{l}\text { Turleau } \\
\text { et al. }\end{array}$ & $\begin{array}{l}\text { Hopkin } \\
\text { et al. } \\
\text { group A }\end{array}$ & $\begin{array}{l}\text { Total } \\
\text { results }\end{array}$ \\
\hline Sex & $\mathrm{F}$ & M & $\mathrm{F}$ & & \\
\hline $6 \mathrm{q}$ deletion & q14.1-q15 & q14.1-q15 & $\mathrm{q} 14-\mathrm{q} 16.2$ & $\mathrm{q} 11-\mathrm{q} 16$ & \\
\hline Feeding problems & + & + & - & $83 \%$ & $2 / 3$ \\
\hline Developmental delay & + & + & + & 13 & $3 / 3$ \\
\hline Motor delay & + & + & + & & $3 / 3$ \\
\hline Hypotonia & + & - & + & $90 \%$ & $2 / 3$ \\
\hline Behavioural problems & + & + & & & $2 / 2$ \\
\hline Brain anomalies & + & & $-(\mathrm{CT})$ & $33 \%$ & $1 / 3$ \\
\hline Cardiac abnormalities & - & + & - & $28 \%$ & $1 / 3$ \\
\hline Obesity & $>6 y$ & + & $>6 \mathrm{~m}$ & & $3 / 3$ \\
\hline Hernia & $+(\mathrm{um})$ & + (ing) & $+(\mathrm{um})$ & $71 \%$ hernias & $3 / 3$ \\
\hline Macrocephaly & + & + & - & & $2 / 3$ \\
\hline Prominent forehead & + & + & - & $0 \%$ & $2 / 3$ \\
\hline Rounded face/full cheeks & + & + & + & & $3 / 3$ \\
\hline Almond-shaped eyes & - & - & + & $42 \%$ & $1 / 3$ \\
\hline Short palpebral fissures & + & + & + & $28 \%$ & $3 / 3$ \\
\hline Up-slanting palpebral fissures & - & - & + & $86 \%$ & $1 / 3$ \\
\hline Down-slanting palpebral fissures & + & + & - & $0 \%$ & $2 / 3$ \\
\hline Epicanthal folds & + & + & + & $64 \%$ & $3 / 3$ \\
\hline Thick upper eyelids & + & + & & & $2 / 2$ \\
\hline Strabismus & - & + & + & & $2 / 3$ \\
\hline Bulbous nose & + & + & + & $57 \%$ & $3 / 3$ \\
\hline Large ears & + & + & + & $83 \%$ & $3 / 3$ \\
\hline Small mouth & + & - & + & $21 \%$ & $2 / 3$ \\
\hline Everted lower lip & - & - & + & & $1 / 3$ \\
\hline Thin lips & + & - & - & $57 \%$ & $1 / 3$ \\
\hline High-arched palate & + & - & & $42 \%$ & $1 / 3$ \\
\hline Small hands/feet & + & - & + & $78 \%$ & $2 / 3$ \\
\hline Syndactyly (toe II-III) & + & + & + & & $3 / 3$ \\
\hline Brachymetatarsalia & + & & & & $1 / 1$ \\
\hline
\end{tabular}

$+=$ Feature present; - = feature absent $\mathrm{F}=$ female; $\mathrm{M}=$ male; $\mathrm{m}=$ months; $\mathrm{y}=$ years; $\mathrm{CT}=$ computer tomography; US = ultrasound; AC = Arnold-Chiari; ing = inguinal; um = umbilical.

all 3 patients, all have an early onset of obesity, motor delay, hernia, rounded face with full cheeks, epicanthal folds, short palpebral fissures, bulbous nose, large ears, and syndactyly between toes II and III. Many of these findings are consistent with what has previously been reported from a review of 60 patients presenting with deletions encompassing the long arm of chromosome 6 [Hopkin et al., 1997]. In this review, 3 distinct phenotypes were described on the basis of the location of the $6 \mathrm{q}$ deletion. All 3 of the above-mentioned patients would have been assigned to group A, del(6)(q11-q16), where hernias, epicanthal folds, bulbous nose, and large ears were also commonly reported features. Our findings suggest that the genes causing this common phenotype would be located in the 6q14 region.
In the DECIPHER database (https://decipher.sanger. ac.uk/), there is a patient reported, patient 140, partially overlapping with patient 1 . The main symptom described in that patient, apart from the developmental delay, is joint laxity, which could not be observed in our 2 patients. The main symptoms described in our patients were not present in that patient $[\mathrm{H}$. van Esch and E. Rosser, personal communication].

Twenty-three genes are located within the $4.2 \mathrm{Mb}$ commonly deleted region (fig. 2B), of which some are interesting and might play a role for the phenotype of these patients. HTR1E (MIM 182132) is a receptor for a serotonin neurotransmitter thought to play a role in various cognitive and behavioural functions including feeding, 
sleep, pain, depression, and learning, and it might explain the behavioural problems and food-seeking behaviour seen in our 2 patients. Association studies have implicated HTR1E as a candidate gene in ADHD patients [LaskySu et al., 2008; Oades et al., 2008] and to be located in close proximity to the breakpoint in a schizophrenia-like psychosis patient with a balanced translocation, $\mathrm{t}(6 ; 11)$ (q14.2;q25) [Jeffries et al., 2003]. ME1 (MIM 154250) encodes a NADP-dependent cytosolic enzyme, expressed in white adipose tissue and involved in modulating lipogenesis. Altered Mel enzyme activity has been associated with obesity in mouse and rat models [Vidal et al., 2006; Qian et al., 2008]. A recent study could show decreased body weight in a knockout mouse model [Yang et al., 2009].

Other genes of interest might be CYB5R4 (MIM 608343), a widely expressed reductase, believed to cause insulin-deficient diabetes [Xie et al., 2004] and SNX14, a membrane protein belonging to the sorting nexin family. SNX14 is mainly expressed in cells of the neuronal lineage and is involved in several stages of intracellular trafficking [Carroll et al., 2001; Worby and Dixon, 2002].

The 1p31.1 duplication detected in patient 2 contains some genes that could explain the cardiac abnormality not present in patient 1 and in the patient of Turleu et al. [1988]. One of the genes in this region is TNNI3K, a TNNI3- interacting kinase, which has been implemented to a role in cardiac physiology. However, it is not likely that the duplication in this patient contributes to the phenotype shared by our 2 patients and the one by Turleu et al. [1988] and also seen in group A by Hopkins et al. [1997].

Haploinsufficiency of the gene SIM1, located at 6q16.3, has been suggested as being responsible for the severe obesity [Villa et al.; 1995; Faivre et al., 2002; Bonaglia et al., 2008]. Previous studies in mice have shown that expression of the SIM1 gene is involved in the regulation of body weight [Michaud et al., 1998]. Moreover, the commonly deleted region reported here might affect the gene expression of SIM1 and thereby causing the obesity through alteration of the chromatin structure. Recent studies showed that CNVs can have an effect on gene expression of genes as far as $2-7 \mathrm{Mb}$ away from the CNV by influencing the transcriptome [Henrichsen et al., 2009]. However, in our 2 patients the deletion is $13 \mathrm{Mb}$ upstream of the SIM1 gene, thus, altered SIM1 expression is less probable and thereby might not explain the obesity seen in our 2 patients.

In spite of this difference, in the location of the deletion our patients bare a striking resemblance to the other reported patients with haploinsufficiency of the SIM gene, suggesting that other genes might also have been responsible for the obesity and specific phenotype seen in our patients. In conclusion, the deletion at $6 \mathrm{q} 14.1 \mathrm{q} 15$ seen in our 2 patients and the one previously reported by Turleau et al. [1988], suggest that this might represent a new clinically recognisable microdeletion syndrome charcterised by developmental delay, early-onset obesity, hernia, rounded face with full cheeks, epicanthal folds, short palpebral fissures, bulbous nose, large ears, and syndactyly between toes II and III. This is further supported by the patients in group A in the review by Hopkins et al. [1997]. Further high-resolution studies of patients with deletions in the 6q14q15 region will facilitate genotypephenotype correlations for specific genes responsible for the obesity and specific phenotype seen in these patients.

\section{Acknowledgements}

We are very grateful to the participating families for their cooperation. This work was supported by grants from the Sävstaholm Society and the Borgström Foundation. Patients have been submitted to DECIPHER (https://decipher.sanger.ac.uk/).

\section{References}

Bochukova EG, Huang N, Keogh J, Henning E, Purmann C, et al: Large, rare chromosomal deletions associated with severe early-onset obesity. Nature 463:666-670 (2010).

Bonaglia MC, Ciccone R, Gimelli G, Gimelli S, Marelli S, et al: Detailed phenotype-genotype study in five patients with chromosome 6 q16 deletion: narrowing the critical region for Prader-Willi-like phenotype. Eur J Hum Genet 16:1443-1449 (2008).
Carroll P, Renoncourt Y, Gayet O, De Bovis B Alonso S: Sorting nexin-14, a gene expressed in motoneurons trapped by an in vitro preselection method. Dev Dyn 221:431-442 (2001).

Chong SS, Pack SD, Roschke AV, Tanigami A, Carrozzo R, et al: A revision of the lissencephaly and Miller-Dieker syndrome critical regions in chromosome 17p13.3. Hum Mol Genet 6:147-155 (1997).
Faivre L, Cormier-Daire V, Lapierre JM, Colleaux L, Jacquemont $S$, et al: Deletion of the sim1 gene (6q16.2) in a patient with a PraderWilli-like phenotype. J Med Genet 39:594596 (2002).

Gilhuis HJ, van Ravenswaaij CM, Hamel BJ, Gabreels FJ: Interstitial 6q deletion with a Prader-Willi-like phenotype: a new case and review of the literature. Eur J Paediatr Neurol 4:39-43 (2000). 
Grati FR, Lalatta F, Turolla L, Cavallari U, Gentilin B, et al: Three cases with de novo $6 \mathrm{q}$ imbalance and variable prenatal phenotype. Am J Med Genet A 136:254-258 (2005).

-Henrichsen CN, Chaignat E, Reymond A: Copy number variants, diseases and gene expression. Hum Mol Genet 18:R1-R8 (2009).

-Hopkin RJ, Schorry E, Bofinger M, Milatovich A, Stern HJ, et al: New insights into the phenotypes of $6 \mathrm{q}$ deletions. Am J Med Genet 70: 377-386 (1997).

- Jeffries AR, Mungall AJ, Dawson E, Halls K, Langford CF, et al: Beta-1,3-Glucuronyltransferase-1 gene implicated as a candidate for a schizophrenia-like psychosis through molecular analysis of a balanced translocation. Mol Psychiatry 8:654-663 (2003).

Klein OD, Cotter PD, Moore MW, Zanko A, Gilats $\mathrm{M}$, et al: Interstitial deletions of chromosome 6q: genotype-phenotype correlation utilizing array CGH. Clin Genet 71:260-266 (2007).

Lasky-Su J, Neale BM, Franke B, Anney RJ, Zhou $\mathrm{K}$, et al: Genome-wide association scan of quantitative traits for attention deficit hyperactivity disorder identifies novel associations and confirms candidate gene associations. Am J Med Genet B Neuropsychiatr Genet 147B:1345-1354 (2008).

Le Caignec C, Swillen A, Van Asche E, Fryns JP, Vermeesch JR: Interstitial 6q deletion: clinical and array CGH characterisation of a new patient. Eur J Med Genet 48:339-345 (2005).

Lee JA, Lupski JR: Genomic rearrangements and gene copy-number alterations as a cause of nervous system disorders. Neuron 52:103121 (2006).
Michaud JL, Rosenquist T, May NR, Fan CM: Development of neuroendocrine lineages requires the bHLH-PAS transcription factor SIM1. Genes Dev 12:3264-3275 (1998).

Oades RD, Lasky-Su J, Christiansen H, Faraone SV, Sonuga-Barke EJ, et al: The influence of serotonin- and other genes on impulsive behavioral aggression and cognitive impulsivity in children with attention-deficit/hyperactivity disorder (ADHD): findings from a family-based association test (FBAT) analysis. Behav Brain Funct 4:48 (2008).

Qian S, Mumick S, Nizner P, Tota MR, Menetski $\mathrm{J}$, et al: Deficiency in cytosolic malic enzyme does not increase acetaminophen-induced hepato-toxicity. Basic Clin Pharmacol Toxicol 103:36-42 (2008).

Stein CK, Stred SE, Thomson LL, Smith FC, Hoo JJ: Interstitial 6q deletion and Prader-Willilike phenotype. Clin Genet 49:306-310 (1996).

-Stern RF, Roberts RG, Mann K, Yau SC, Berg J Ogilvie CM: Multiplex ligation-dependent probe amplification using a completely synthetic probe set. Biotechniques 37:399-405 (2004).

Thuresson AC, Bondeson ML, Edeby C, Ellis $\mathrm{P}$, Langford C, et al: Whole-genome arrayCGH for detection of submicroscopic chromosomal imbalances in children with mental retardation. Cytogenet Genome Res 118: 1-7 (2007).

-Turleau C, Demay G, Cabanis MO, Lenoir G, de Grouchy J: 6q1 monosomy: a distinctive syndrome. Clin Genet 34:38-42 (1988).

Walley AJ, Asher JE, Froguel P: The genetic contribution to non-syndromic human obesity. Nat Rev Genet 10:431-442 (2009).
Walters RG, Jacquemont S, Valsesia A, de Smith AJ, Martinet D, et al: A new highly penetrant form of obesity due to deletions on chromosome 16p11.2. Nature 463:671-675 (2010).

Varela MC, Simoes-Sato AY, Kim CA, Bertola DR, De Castro CI, Koiffmann CP: A new case of interstitial 6 q16.2 deletion in a patient with Prader-Willi-like phenotype and investigation of SIM1 gene deletion in 87 patients with syndromic obesity. Eur J Med Genet 49: 298-305 (2006).

Wentzel C, Fernstrom M, Ohrner Y, Anneren G, Thuresson AC: Clinical variability of the 22q11.2 duplication syndrome. Eur J Med Genet (2008).

Vidal O, Varona L, Oliver MA, Noguera JL, Sanchez A, Amills M: Malic enzyme 1 genotype is associated with backfat thickness and meat quality traits in pigs. Anim Genet 37: 28-32 (2006).

-Villa A, Urioste M, Bofarull JM, Martinez-Frias ML: De novo interstitial deletion q16.2q21 on chromosome 6. Am J Med Genet 55:379383 (1995).

Worby CA, Dixon JE: Sorting out the cellular functions of sorting nexins. Nat Rev Mol Cell Biol 3:919-931 (2002).

Xie J, Zhu H, Larade K, Ladoux A, Seguritan A, et al: Absence of a reductase, NCB5OR, causes insulin-deficient diabetes. Proc Natl Acad Sci USA 101:10750-10755 (2004).

- Yang X, Deignan JL, Qi H, Zhu J, Qian S, et al: Validation of candidate causal genes for obesity that affect shared metabolic pathways and networks. Nat Genet 41:415-423 (2009). 